IZA DP No. 6883

What Determines Religious School Choice?

Theory and Evidence from Rural Bangladesh

M. Niaz Asadullah

Rupa Chakrabarti

Nazmul Chaudhury

September 2012 


\title{
What Determines Religious School Choice? Theory and Evidence from Rural Bangladesh
}

\author{
M. Niaz Asadullah \\ University of Reading, \\ SKOPE, University of Oxford and IZA \\ Rupa Chakrabarti \\ University of Reading \\ Nazmul Chaudhury \\ World Bank \\ Discussion Paper No. 6883 \\ September 2012 \\ IZA \\ P.O. Box 7240 \\ 53072 Bonn \\ Germany \\ Phone: +49-228-3894-0 \\ Fax: +49-228-3894-180 \\ E-mail: iza@iza.org
}

\begin{abstract}
Any opinions expressed here are those of the author(s) and not those of IZA. Research published in this series may include views on policy, but the institute itself takes no institutional policy positions. The IZA research network is committed to the IZA Guiding Principles of Research Integrity.

The Institute for the Study of Labor (IZA) in Bonn is a local and virtual international research center and a place of communication between science, politics and business. IZA is an independent nonprofit organization supported by Deutsche Post Foundation. The center is associated with the University of Bonn and offers a stimulating research environment through its international network, workshops and conferences, data service, project support, research visits and doctoral program. IZA engages in (i) original and internationally competitive research in all fields of labor economics, (ii) development of policy concepts, and (iii) dissemination of research results and concepts to the interested public.
\end{abstract}

IZA Discussion Papers often represent preliminary work and are circulated to encourage discussion. Citation of such a paper should account for its provisional character. A revised version may be available directly from the author. 


\section{ABSTRACT \\ What Determines Religious School Choice? Theory and Evidence from Rural Bangladesh}

This paper looks at the determinants of school selection in rural Bangladesh, focusing on the choice between registered Islamic and non-religious schools. We consider a two period framework where children are a source of old age transfers. The amount of old age transfers made by children as adults is influenced both by their schooling and by parental religiosity. Parents also derive utility from educating a proportion of their children in madrasahs in a way that reflects their own religious values. We investigate how household income, religious preferences, schooling costs, and school quality affect the proportion of children sent to each school type. Using a unique dataset on secondary school age children from rural Bangladesh, we find that madrasah enrolment falls as household income increases. At the same time, more religious households, and those that live further away from a non-religious school are more likely to send their children to madrasahs. However, in contrast to the theory, we find that Islamic school demand does not respond to the average quality of schools in the locality.

JEL Classification: D04, 121, O15

Keywords: $\quad$ school choice, madrasah education, Bangladesh

Corresponding author:

M. Niaz Asadullah

School of Economics

University of Reading

PO Box 218

Whiteknights

Reading, RG6 6AA

United Kingdom

E-mail:m.asadullah@reading.ac.uk

\footnotetext{
This paper is an output of the International Growth Centre (IGC). Niaz Asadullah gratefully acknowledges additional support from the Leverhulme Trust UK and the hospitality of the Research and Evaluation Division (RED) of BRAC, where the final version of this paper was prepared. We are grateful to Nigar Hashimzade and Mark Guzman for guidance and advice and Danny Cohen-Zada for an informed discussion of the issues surrounding the paper. We would like to thank Zihad Hassan who managed the survey work with utmost professional competence. Lastly, we would also like to thank seminar participants at Reading University, participants at the 2011 Association for the Study of Religion, Economics and Culture (ASREC) Conference, $11^{\text {th }}$ UKFIET International Conference on Education and Development (September 2011) and IGC seminar in Dhaka (March 2012) for their helpful comments on an earlier version of the paper. The usual disclaimers apply.
} 


\section{Introduction}

For geo-political and international security related reasons, there is growing global interest in Islamic faith schools or madrasahs. In Bangladesh and other South Asian countries such as India and Pakistan, these schools allegedly cater to a large number of students and thrive in poor and isolated communities. Enrolment in madrasahs, it is argued, is on the rise. Madrasahs may promote extreme political and religious viewsand gender norms and arguably do not impart significant marketable skills (Asadullah and Chaudhury, 2010; World Bank, 2010). Therefore it begs the question why Muslim households choose to send their children to these schools.

In a country with nearly $40 \%$ of the population living below the poverty line, household choice of religious schooling in Bangladesh is popularly perceived in terms of poverty and an inadequacy of mainstream schools (Evans, 2008). The weight of the evidence from existing research indicates that non-religious ${ }^{1}$ (government owned and financed) schools are of better quality (Asadullah, Chaudhury and Dar, 2007) so that children are likely to enrol in madrasahs only in areas where there is insufficient provision of non-religious schools. Nonetheless, enrolment decisions can favour madrasahs owing to economic considerations even in better provided areas. Although many madrasahs are fee-charging, they present a cheaper alternative to non-religious schools (World Bank, 2010) and are hence likely to appeal to relatively poorer households. The quality of non-religious schools in rural locations may not be sufficiently high to attenuate the overall demand for madrasahs. However, these hypotheses remain untested given limited research on parental choice of schools in Muslim countries ${ }^{2}$.

Religious school choice is however a relatively well researched topic for developed countries. Several European countries such as Ireland, Netherlands, and the United Kingdom have a large number of state-financed religious schools, whilst the United States has a significant number of private schools that operate under a religious orientation. The extant literature on faith school choice in these countries is suggestive of a variety of reasons for demand for religious education (Sander, 2005; Cohen-Zada and Justman,

\footnotetext{
${ }^{1}$ The term "non-religious" indicates that the school admits students from all faith groups.

${ }^{2}$ There are three recent studies on faith schools in developing countries -Wodon and Ying (2009) and Backiny-Yetna and Wodon (2009a, 2009b). But none of these focuses on the question of school choice they only present evidence on the relative performance of different school types.
} 
2005; Cohen-Zada, 2006; Cohen-Zada and Sander, 2008). Cohen-Zada (2006) models the decision of religious parents to send their children to private religious schools in terms of parental desire to protect their children from external influences and thus preserve their religious identity. Using data on Catholic private school enrolment in the US, he finds that when the share of the religious minority in the local population grows, and outside influences become less threatening, the demand for separate religious schooling among the members of the religious group decreases. Sander (2005) finds that the probability of children attending Catholic schools is explained by Catholic parents’ religiosity (proxied by church attendance). In a more recent study, Cohen-Zada and Sander (2008) quantify the religious factor in private education in the US by estimating a random utility model of school-choice in which households choose among public, private/non-sectarian, Catholic and Protestant schools. They find that both religion and religiosity have important effects on the demand for Catholic schools ${ }^{3}$.

Some of the above results can help shed some light on religious school choice in rural Bangladesh. Religious preferences may be important in explaining madrasah enrolment, but at the same time, household choices can be driven by economic costs and benefits. In this latter respect, the household decision for a family in rural Bangladesh is not dissimilar to that of a family in a developed country. Irrespective of their mode of finance and management, faith schools (Catholic and/or Church affiliated) in the US are considered to be superior to public schools in terms of quality (for example see Neal, 1997). In the US, these faith schools are overwhelmingly under private management and charge high fees which limit participation of children from poorer socio-economic backgrounds. Public school enrolment is thus inversely correlated with household income. In Bangladesh, it is the religious schools which offer a cheaper, but lower quality alternative to non-religious schools. In this sense, parents in both settings face a trade-off between school cost and school quality ${ }^{4}$.

\footnotetext{
${ }^{3}$ However, in a companion paper, Cohen-Zada and Sander (2008b) relax the assumption that religiosity (attendance at religious services) is an exogenous determinant of religious school choice.

${ }^{4}$ Research on household school choice in developing countries also confirms the relative importance of quality. For instance, Alderman, Orazem and Paterno (2001) report that the poorest households in Pakistan send children to fee-charging private schools (and that utilization increases with income) when public schools are of poor quality.
} 
For historical reasons, Bangladesh was endowed with a relatively large governmentregistered madrasah system (Asadullah and Chaudhury, 2009a; World Bank, 2010) ${ }^{5}$. These madrasahs are recognised by the state and follow a standardized curriculum which also includes subjects such as mathematics, languages and science, in addition to Islamic studies. This distinguishes Bangladesh from other countries in South Asia (where madrasahs are typically unrecognised by the state and focus almost exclusively on religious instruction), and presents an ideal context in which to study household choice between registered madrasahs and non-religious schools. So far, this question has not been addressed empirically owing to the lack of household survey based information on enrolment in Islamic religious schools.

In this paper, we use data from a purposefully designed rural household survey QSSMEB (Quality of Secondary School Madrasa Education in Bangladesh), which examines the incidence of madrasah education in Bangladesh, and households' decisions to educate children in madrasahs. The QSSMEB survey was designed to present definitive statements regarding the choice of madrasahs among households as a schooling choice. Therefore, we go beyond simple tabulations and present regression estimates of determinants of madrasah enrolment. The regression specification is motivated by predictions from a two-period model of school choice.

One of the interesting features of school enrolment in rural Bangladesh is that a household may educate some of its children in a madrasah while the others attend a non-religious school. In the QSSMEB data, nearly 70\% households with at least two secondary school age children chose madrasah education for some children and school education for the others. We thus develop a simple two period framework to explain how a household chooses the proportion of children to send to each school type. The model treats children as a source of old age transfers where the amount of transfers is determined by the labour market outcome of the children as well as their traditional and religious values ${ }^{6}$. These

\footnotetext{
${ }^{5}$ The first registered madrasah, initially known as the Calcutta Madrasah, was established in 1781 in Calcutta. The madrasah taught both religious and secular subjects, and was supposed to be a model for madrasah reform for the rest of India. After the India-Pakistan partition in 1947, it was transferred to Dhaka. This encouraged significant growth in the number of registered madrasahs throughout East Pakistan. In the early 1980s there was a further proliferation of Aliyah madrasahs in response to a series of reform measures initiated by the government.

${ }^{6}$ There is experimental evidence from South Asia which suggests a link between religiosity and pro-social behaviour. For instance, in a field study conducted in India, Ahmed (2009) finds that madrasah students are
} 
values are in turn influenced by their parents' religiosity as well as their schooling. Parents also derive satisfaction from sending a proportion of their children to madrasahs in a way that reflects their own religious values. Keeping in mind that children who are madrasah graduates are likely to earn less as adults, parents need to balance the economic motives of educating children with the non-economic motives of school choice which are driven by their personal beliefs. The model then examines how factors such as household income, religious preferences, schooling costs and school quality affect the proportion of household children educated in each school type.

By way of combining economic theory with field-based evidence, our paper makes a unique contribution to the current international literature on madrasah education. It builds on two closely related studies on the issue, namely, Newhouse and Beegle (2006) and Andrabi, Das, Khwaja, and Zajonc (2006). Newhouse and Beegle present a model to explain household choice of a school type based on their wealth and preference for academic achievement. Whilst their analysis is a useful starting point, they do not explicitly focus on religious school choice. Instead, they focus on the decision to send children to private (religious or non-religious) or public schools in Indonesia.

On the other hand, Andrabi, Das, Khwaja, and Zajonc (2006) focus on the question of religious school enrolment and present descriptive evidence on the issue for Pakistan. The authors find that school choice by households in their data appears to be driven neither solely by poverty, nor by the religious mindedness of households. On the basis of household censuses and surveys, it is shown that one household could send one of its children to a madrasah, another to a public school, and a third to one of the increasingly common private schools. Nonetheless, the households that choose madrasahs account for a very small proportion in the study sample which limits the scope for a formal statistical analysis of the issue. Another study of school choice in Pakistan is carried out by Alderman, Orazem and Paterno (2001); however, they do not address the issue of religious school choice per se. In their study, the focus is on household choice between private schools, public schools, and not sending children to school at all.

significantly more cooperative in the public goods game and significantly more generous in the dictator game than other students. 
Research on school choice in Muslim communities can be complicated by the fact that the institution of madrasah varies widely in terms of what is taught, how it is taught, and what view of religion is imparted to students. In addition to the large number of registered madrasahs that operates with complete oversight of the government, there is an unknown number of madrasahs in Bangladesh which are not recognised by the state. This latter group primarily specializes in religious education and does not teach marketable skills. Therefore, unrecognised madrasahs do not serve as a substitute for formal schools in the labour market. Moreover, the enrolment share of these madrasahs in rural Bangladesh is very small (World Bank, 2010). For these two reasons, this study does not explore the question of unrecognised madrasah attendance.

The rest of the paper is organized as follows. Section 2 presents background information on madrasahs and the mainstream education system in Bangladesh. Section 3 presents a simple theoretical model of school choice. Section 4 discusses the dataset whilst empirical results are presented in Section 5. Section 6 concludes.

\section{Background}

Islamic religious schools in Bangladesh are almost entirely in the non-state sector, operating at both primary and secondary levels. Moreover, the majority of the staterecognised schools also benefit fiscally from the state under the Private-Public Partnership (PPP) model. Little systematic information is available on those religious schools that remain outside the state sector and are unrecognised by the state. There is a perceived difference among various madrasahs in terms of in-school conduct and curriculum content. Indeed, madrasahs operating at primary or secondary levels in Bangladesh are classified in two broad categories: Aliyah madrasahs and Quomi madrasahs. Outside the primary/secondary sector ${ }^{7}$, there is a large number of pre-primary Islamic education institutions which are of two types, Maktab (or Nourani madrasah) and Furqania/Hafizia madrasahs $^{8}$. In this study, we focus on secondary education choices and outcomes only.

\footnotetext{
${ }^{7}$ As in other South Asian countries, the Bangladeshi education system consists of four main levels: primary school (five years of study), secondary school (five years), and higher secondary education (two years) and tertiary (graduate and post-graduate) education.

${ }^{8}$ Abdalla, Raisuddin and Hussein (2004) provide an excellent discussion of the curriculum and structure of primary and pre- primary religious and non-religious schools within the state regulated sector.
} 
The establishment of Aliyah madrasahs and their activities follow government regulations as prescribed by the Madrasah Education Board. The Board approves curriculum for all registered madrasahs from secondary to post-graduate level. For a madrasah operating at any level, there are clearly prescribed requirements for state recognition and support. In terms of curriculum content, Aliyah madrasahs offer a hybrid education where students are taught both religious subjects and modern general education.

The secondary level of the Aliyah stream is known as Dakhil which spans grades 6 to 10 . As inthe mainstream education system, at the end of Dakhil education students appear in a public examination which is organized by the Bangladesh Madrasah Education Board. The Dakhil certificate is equivalent to the Secondary School Certificate (SSC) obtained after successful completion of secondary education from non-religious schools. There are four Dakhil madrasah curriculum groupings: (a) General group, where the focus is on languages, mathematics, religious studies, and social studies; (b) Science group, where in addition to languages, mathematics, and religious studies, students are examined in computer science, physics, chemistry, and biology; (c) Muzabbid group, where students are taught in additional religious subjects such as Quran, hadith, and fiqh; (d) Hifzul Quran group, where students specialize in memorizing the Quran.

Similarly, students in non-religious secondary schools can opt for different group specializations such as science, arts and commerce. However, they cannot specialise in religious studies; at most $10 \%$ of the curriculum comprises of Islamic education ${ }^{9}$. Therefore, in comparison to mainstream non-religious schools, Aliyah secondary madrasahs give students the option to specialise in general, non-religious stream as well as Islamic theology.

The international discourse uses the word "madrasah" as a catchall term. However, depending on level of education and/or government recognition, madrasahs differ in types. First, a madrasah can mean something as simple as a pre-school institution, where children learn the Quran alongside a few religious practices. Second, it can mean a primary or secondary school that serves as a substitute for mainstream non-religious education. Third, it can also mean a seminary established to train proper clerics in

\footnotetext{
${ }^{9}$ Non-Muslim students study their own religion or are allowed to opt out of religious education.
} 
classical Islamic religious knowledge. We, therefore, define madrasah enrolment by types.

World Bank (2010) presents the market share of different types of madrasahs in rural Bangladesh using the QSSMEB survey data which was collected in 2008. According to the QSSMEB Census, there are 32,372 children between the ages of 6 and 18 of which 17.52\% (i.e. 5763 children) report the last school attended as a madrasah. However, many students may have first enrolled in a madrasah but have subsequently moved to a school. When accounting for this fact, 19.78\% (6404 children) have enrolled at least once in madrasahs in the past. Lastly, when restricted to the population of 24,440 children who are currently enrolled, the share of madrasahs rises to $18.79 \%$. These numbers are consistent with household survey based estimates of the market share of madrasahs.

Table 1 below summarizes data on the market share of madrasahs by levels of education. The share is found to be much higher in secondary education. These figures are close to estimates available from other sources. For instance, according to the large scale nationwide household survey of CAMPE (Campaign for Popular Education), madrasahs account for $16 \%$ of total enrolment in the primary sector whilst our estimates range between 13.8\%and 15.7\%. Unfortunately, apart from CAMPE, there is no other source of comparable data on madrasah enrolment.

Table 1: Madrasah enrolment in rural Bangladesh

\begin{tabular}{|c|c|c|}
\hline & $\begin{array}{c}\text { Overall } \\
\text { share }\end{array}$ & Breakdown by madrasah type \\
\hline \multicolumn{3}{|c|}{ QSSMEB 2008 census(24841 households) } \\
\hline$\%$ share of primary enrolment & $13.8 \%$ & $\begin{array}{l}8.14 \% \text { is in registered madrasah and } 5.4 \% \text { is in } \\
\text { unregistered madrasah }\end{array}$ \\
\hline$\%$ share of secondary enrolment & $22.1 \%$ & $\begin{array}{l}18.5 \% \text { is in registered madrasah and } 3.6 \% \text { is in } \\
\text { unregistered madrasah }\end{array}$ \\
\hline \multicolumn{3}{|c|}{ QSSMEB 2008 survey(2400 households) } \\
\hline$\%$ share of primary enrolment & $15.7 \%$ & $\begin{array}{l}9.48 \% \text { is in registered madrasah and } 5.9 \% \text { is in } \\
\text { unregistered madrasah }\end{array}$ \\
\hline$\%$ share of secondary enrolment & $24.5 \%$ & $\begin{array}{l}20.3 \% \text { is in registered madrasah and } 4.2 \% \text { is in } \\
\text { unregistered madrasah }\end{array}$ \\
\hline
\end{tabular}


Finally, differences in curriculum aside, registered schools and madrasahs differ significantly in terms of costs and physical inputs. Table 2 reports the average profile of non-religious secondary schools and registered madrasahs in rural Bangladesh. On average, schools have a bigger land area, are better inspected by the government and have a larger proportion of trained teachers. They also charge higher fees and pay a higher salary to their teachers. Looking at average test scores in mathematics and English, we find that non-religious schools perform slightly better, while as expected, madrasahs have a clear advantage when it comes to religious studies. However, it is worth noting that while non-religious schools tend to achieve somewhat higher scores, the average performance is rather poor for both types of schools.

\section{Table 2: Profile of an average non-religious secondary school and madrasah}

\begin{tabular}{lcc}
\hline & $\begin{array}{c}\text { Non-religious } \\
\text { school }\end{array}$ & $\begin{array}{c}\text { Registered } \\
\text { Madrasah }\end{array}$ \\
\cline { 2 - 3 } School land area (in logs) & 4.91 & 4.77 \\
School inspected(1 if yes) & 0.82 & 0.69 \\
Student fees (in logs) & 4.95 & 4.20 \\
\% of female teachers & 18 & 9 \\
\% of trained teachers & 69 & 25 \\
Teacher salary (in logs) & 8.63 & 8.29 \\
Grade 8 student score in maths (\% of answers correct) & 35.57 & 33.14 \\
Grade 8 student score in English (\% of answers correct) & 36.88 & 26.69 \\
Grade 8 student score in Islam (\% of answers correct) & 69.94 & 81.54 \\
\cline { 2 - 3 } N & 206 & 123 \\
\hline Source: Based on World Bank (2010) and QSSMEB survey 2008. &
\end{tabular}

\section{A theoretical model of household demand for madrasah education}

As pointed out earlier, religious school choice has not been studied extensively in developing, and in particular, Islamic countries. However, one example is Newhouse and Beegle (2006) who address the issue for Indonesia where households have the option of sending their children to private or public (religious or non-religious) schools. To formalize the problem of school choice, they set up a two-period model where parents select a school in Period 1, whilst the child transfers an amount of income determined by the quality of their education, which is consumed by the parent in the second period. Parents' utility is a positive function of their consumption in the two periods, their taste for school quality (or valuation of academic achievement) as well as non-academic 
characteristics of the school such as safety, religious affiliation, convenience and discipline.

The Newhouse and Beegle model makes two predictions. First, a parent that places a higher value on education is more likely to send their child to public schools, which are assumed to be of higher average quality. Second, holding other factors constant, wealthier households are more likely to send their children to private school.

In Bangladesh, most of the non-religious schools are either state managed or aided. The share of the unrecognised madrasahs in secondary education is insignificant. Therefore, the real choice lies between state-recognised secondary schools and madrasahs, rather than between public and private faith schools. In this paper, we develop a theoretical model to explain the household choice of madrasahs over non-religious schools in rural areas. Unlike in the Newhouse and Beegle model where religious affiliation of the school is considered a part of "other" factors, we specifically model both the impact of the religiousness of the school curriculum as well as parental religiosity on the level of transfers. Parents also derive direct satisfaction from their school choice decision relative to their religiosity. In addition, our model specifically addresses the observed fact that a proportion of children in a given household might attend madrasahs while the rest attend non-religious schools.

We consider a simple, two-period model, where individuals work when young, earn an exogenous income, $y$, and send their children to school ${ }^{10}$. Schools are of two types, nonreligious secondary schools, which are denoted by $s$ and state recognised Aliyah madrasahs, denoted by $m$.

Schooling costs, denoted by $P_{s}$ and $P_{m}$ respectively, include both tuition and travel cost ${ }^{11}$. Empirical evidence suggests that tuition for registered Aliyah madrasahs is typically less than that of non-religious schools, and they are also likely to be geographically more

\footnotetext{
${ }^{10}$ For the purposes of this model, we only focus on households that send their children to school. We are thus abstracting away from the issue of child labour, whereby some parents might decide not to send their children to school at all. In our sample, $72 \%$ of secondary school age children attend a secondary school of some type.

${ }^{11}$ This is done for simplicity. We could split up total schooling cost into $P_{j}=Q_{j}+D_{j}$, where $Q_{j}$ represents tuition, while $D_{j}$ represents distance or travel cost. Although tuition in secular schools is higher, we can allow for the travel cost to the madrasah to be higher or lower than travel cost to a non-religious school, depending on the location of schools in a particular village.
} 
accessible than secondary schools; thus $P_{s}>P_{m}$. We further assume that both $P_{s}$ and $P_{m}$ are strictly less than $y$, and that $y-P_{m}>\underline{y}$, where $\underline{y}$ is a subsistence level of income.The number of children is normalized to 1 . Parents send a proportion $a$ of their children to madrasahs, and a proportion $1-a$ to non-religious schools.

In the second period, parents get old age transfers from their children. For simplicity, we assume that there is no other income in period 2; however, adding this will not make a significant difference to the analysis. Transfers $(T)$ are a proportion of the wage $(w)$ earned by the child as an adult. This proportion is determined by their traditional and religious values as an adult. In the case of rural households, growing up in a more religious home and attending a more religious school, is likely to instil stronger traditional and religious values in a child. One aspect of these traditional values is looking after parents in their old age. Let $Z_{j}$ be an index of these adult values for a child who was educated in school type $j$. Thus,

$$
T_{j}=Z_{j} w_{j}, \text { wherej }=s, m
$$

A child's adult wage is determined by the type of school its parents chose in period 1 . Aliyah madrasahs teach fewer marketable skills, therefore, $w_{s}>w_{m}{ }^{12}$. We can also think of these wages as a proxy for school quality, although it is worth keeping in mind that in some rural areas, school quality may be low across the board (as seen in Table 2).

The traditional and religious values of a child in adulthood, $Z_{j}$, is an increasing function of both the religious aspect of their school curriculum, as well as their parent's religiosity: Thus,

$$
Z_{j}=Z_{j}\left(z_{j}, Z_{P}\right)
$$

where $z_{j}$ represents the religious aspect of the curriculum in school type $j$ (since madrasahs have a more religious curriculum, $z_{m}>z_{s}$ ), and $Z_{P}$ is the parent's religiosity, which is taken as given in this two period model. In general, $Z_{s}$ and $Z_{m}$ can have different forms.

\footnotetext{
${ }^{12}$ See Asadullah (2009) for evidence on the negative correlation between wages and madrasah attendance.
} 
Finally, the total amount of transfers received by the parent in period 2 is a weighted average of transfers from madrasah-educated and non-religious school-educated children, and is given by

$$
T=a T_{m}+(1-a) T_{s}
$$

Apart from consumption in the first and second period ( $c_{1}$ and $c_{2}$, respectively), parents also derive utility from sending a certain proportion of their children to madrasahs in a way that reflects their religious values. The lifetime utility of the representative parent is given by

$$
U=\ln c_{1}+\beta \ln c_{2}+\gamma v\left(\frac{a}{z_{P}}\right)
$$

$$
\begin{array}{ll}
\text { where } & v^{\prime}>0 \text { if }\left(a / Z_{P}\right)<1 \\
& v^{\prime}=0 \operatorname{if}\left(a / Z_{P}\right)=1 \\
& v^{\prime}<0 \text { if }\left(a / Z_{P}\right)>1, \text { and } \\
& v^{\prime \prime}<0 \text { for all }\left(a / Z_{P}\right) . \\
& 0<\beta<1, \text { and } \\
& \gamma>0
\end{array}
$$

We further assume that $v(0)=0$, and that there is a lower bound on parental religiosity, $\underline{Z_{P}}$, such that $v\left(\frac{a}{Z_{P}}\right)=0$. This is graphically illustrated in Appendix 1 .

The first two terms of the utility function are the standard consumption terms, while the last term in the utility function can be thought of as a "school choice" term. This school choice term in Equation (4) says that sending a certain proportion of children to madrasahs yields the highest utility when this proportion best matches the religious values of the parent, i.e. when $\left(a / Z_{P}\right)=1$. A parent who is not very religious, but still sends a large proportion of children to a madrasah (because it is the cheaper or more accessible alternative), gains lower utility from the school choice term, since in their case, $\left(a / Z_{P}\right)>$ 1. Similarly, for a parent who is very religious, but does not send a large enough proportion of children to a madrasah, the additional benefit from the school choice term is not very high. 
The utility function in effect says that parents want their children to be similar to themselves in their religious values. Parents thus try to match their school choice $(a)$,to their own religiosity $\left(Z_{P}\right)$. However, religious parents do not simply send all their children to madrasahs. The religious motivation for school choice is only part of the story. Parents also care about their consumption in both periods, which, as the budget constraints below show, depend on income, school costs, and the potential transfers they get from their children in old age.

The problem for the representative parent is to choose $a$, the proportion of children to send to madrasah, in order to maximise lifetime utility.

$$
\max _{a \in[0,1]} \ln c_{1}+\beta \ln c_{2}+\gamma v\left(\frac{a}{Z_{P}}\right)
$$

subject to,

$$
\begin{gathered}
c_{1}=y-a P_{m}-(1-a) P_{s} \\
c_{2}=a T_{m}+(1-a) T_{s}
\end{gathered}
$$

It can be readily verified that the first order condition for this problem is:

$$
\frac{P_{s}-P_{m}}{c_{1}}-\beta \frac{\left(T_{s}-T_{m}\right)}{c_{2}}+\gamma v^{\prime}\left(\frac{a}{Z_{P}}\right)\left(\frac{1}{Z_{P}}\right)=0
$$

We can now substitute equations (1) and (2) into equation (5) to express the first order condition in terms of the different parameters of the model. In particular, we can express the first order condition as:

$$
F\left(a, y, P_{s}, P_{m}, w_{s}, w_{m}, z_{s}, z_{m}, Z_{P}\right)=0
$$

Using the implicit function theorem ${ }^{13}$, we can now see how the optimal proportion of children educated in madrasahs, varies with changes in school costs, school quality (as

\footnotetext{
${ }^{13}$ The effect of each parameter on $a$, the proportion of children enrolled in madrasahs, can be calculated as follows; using the parameter $y$ as an example, we know that $\partial a / \partial y=-\left(F_{y} / F_{a}\right)$.
} 
proxied by future wages), the religiousness of the school curriculum, and parental religiosity.

\section{Comparative statics}

From equation (6), it can be shown that as parental income $y$ increases, the proportion of children enrolled in madrasahs decreases. This is because an increase in $y$ means that parents can afford the more expensive non-religious schools and thus they educate a smaller proportion of their children in madrasahs ${ }^{14}$. As madrasahs become more expensive, i.e. as the cost of madrasahs $\left(P_{m}\right)$ increases, madrasah enrolment falls. Similarly, if non-religious secondary schools become more expensive, then madrasah enrolment rises.

From equation (6), it can also be shown that if either $w_{S}$ or $z_{S}$ increases, then madrasah enrolment decreases. This is because in both cases, the parameters have a positive impact on the amount of transfers $\left(T_{S}\right)$ that parents can expect in their old age from their nonreligious school educated children. Similarly, if either $w_{m}$ or $z_{m}$ rises, then madrasaheducated children become more valuable as a source of transfers and thus madrasah enrolment also rises.

Finally, we look at the impact of parental religiosity, $Z_{P}$. What happens to madrasah enrolment as parental religiosity changes now depends on how the child's religiosity as an adult, $Z_{j}$, responds to parental religiosity, $Z_{P}$. It will be useful to define the "elasticity” of children's religiosity with respect to their parent's religiosity as:

$$
\varepsilon_{j}=\frac{\partial Z_{j} / \partial Z_{P}}{Z_{j} / Z_{P}}
$$

Using the implicit function theorem, we know that

\footnotetext{
${ }^{14}$ It can be shown that if parents earn income in both periods, then $a$ depends negatively on first period income, as shown here, and positively on second period income. This is not surprising since parents who have a larger second period income do not need to rely as much on transfers, and hence can afford to educate a larger proportion of their children in madrasahs.
} 


$$
\frac{\partial a}{\partial Z_{P}}=-\frac{F_{Z_{P}}}{F_{a}}
$$

From equation (6), it can be easily verified that $F_{a}<0$. Thus, the sign of $\frac{\partial a}{\partial Z_{P}}$ is determined by the sign of $F_{Z_{P}}$, which is given by the following equation:

$$
F_{Z_{P}}=\frac{\beta w_{m} w_{s} Z_{m} Z_{s}}{Z_{P} c_{2}^{2}}\left(\varepsilon_{m}-\varepsilon_{s}\right)-\gamma v^{\prime \prime}\left(\frac{a}{Z_{P}}\right)\left(\frac{a}{Z_{P}^{2}}\right) \frac{1}{Z_{P}}-\gamma v^{\prime}\left(\frac{a}{Z_{P}}\right) \frac{1}{Z_{P}^{2}}
$$

Assuming that $\left(\varepsilon_{m}-\varepsilon_{S}\right) \geq 0{ }^{15}$ and given that $v^{\prime \prime}<0$, we can see that the first two terms in equation (8) are positive. For values of $\left(a / Z_{P}\right)>1$, we know that $v^{\prime}<0$, which implies that the last term in equation (8) is also positive. Furthermore, when $\left(a / Z_{P}\right)=1$, we know that $v^{\prime}=0$. Thus the sign of $F_{Z_{P}}$ is positive for the region where $\left(a / Z_{P}\right) \geq 1$.

In other words, $\frac{\partial a}{\partial Z_{P}}>0$ for the region where $\left(a / Z_{P}\right) \geq 1$; thus madrasah enrolment increases with an increase in parental religiosity.

For the region where $\left(a / Z_{P}\right)<1$, the sign of $\frac{\partial a}{\partial Z_{P}}$ remains positive until a point $\left(\frac{a}{Z_{P}}\right)_{\text {low }}$ below which $v^{\prime}$ has a sufficiently large positive value so as to outweigh the effect of the first two terms in equation (8). In this case, we find that $\frac{\partial a}{\partial Z_{P}}<0$.

Thus, in general, parental religiosity has a positive effect on madrasah enrolment. However, there is a very small range of values of $\left(a / Z_{P}\right)$, for which this effect might be reversed. This occurs where $\left(a / Z_{P}\right)$ is close to zero. For people who are very religious and for whom $Z_{P}$ is very large relative to $a$, the utility from the school choice term in equation (4) is very small, and it is the consumption effect that dominates. Thus if they were to become even more religious, they would need to compensate for their reduction in

\footnotetext{
${ }^{15}$ Generally speaking, $\varepsilon_{m}$ can be greater than or less than $\varepsilon_{s}$. However, it is quite plausible that the religiosity of madrasah-educated children is more responsive to parental religiosity. Madrasahs, with their greater emphasis on religious instruction, are more likely to impart traditional values than non-religious schools, and this includes being more sensitive to one's parent's religiosity. Consequently, we henceforth assume that $\left(\varepsilon_{m}-\varepsilon_{s}\right) \geq 0$.
} 
second period consumption by increasing the proportion sent to non-religious schools (keeping in mind that non-religious school graduates will earn a higher wage, and thus give higher transfers than their madrasah educated counterparts). Table 3 below summarises how $a$ responds to changes in various parameters of the model.

\section{Table 3: Summary of comparative statics}

\begin{tabular}{lc}
\hline \multicolumn{1}{c}{ Parameter } & $\begin{array}{c}\text { Effect on the fraction of children sent } \\
\text { to madrasahs }\end{array}$ \\
\cline { 2 - 2 } Parental income $(y)$ & - \\
Cost of madrasah $\left(P_{m}\right)$ & - \\
Cost ofnon-religious schools $\left(P_{s}\right)$ & + \\
Adult wage of secondary-educated child or non-religious & - \\
school quality $\left(w_{s}\right)$ & + \\
Adult wage of madrasah-educated child or madrasah quality & \\
$\left(w_{m}\right)$ & - \\
Religiousness of non-religious curriculum $\left(z_{s}\right)$ & + \\
Religiousness of madrasah curriculum $\left(z_{m}\right)$ & $+/-$ \\
Parental religiosity $\left(Z_{P}\right)$ & \\
\hline
\end{tabular}

We now move on to the empirical part of the investigation. Due to the nature of the survey data, it was not possible to match up every single parameter from the theoretical model to the empirical study. The comparative statics presented in Table 3 are thus used as a guide for specifying the school choice equation for the regression analysis.

\section{Data}

The empirical analysis presented in this paper is based on a unique survey of households carried out by the authors in 2008, as part of a project on religious school choice in rural Bangladesh. The survey was conducted in 96 villages. The village sample frame comprised of all households where there is at least 1 child aged between 11 and 18 years. The census, on the other hand, covers all households in the sample villages in 12 districts, spread across 6 divisions in Bangladesh. Consequently, it yields a much bigger sample on madrasah enrolment which allows for examining correlations with household attributes in a meaningful manner.

In addition to directly asking the question: "Is the child enrolled in an Islamic education school?”, the QSSMEB survey questionnaire also enquired about any madrasah/school 
the child may have attended previously. The survey questionnaire also has a detailed module on past school choice for all children of school age. Lastly, schooling information is collected not only for resident children, but also for children of the head of household who currently do not live in the household. This is an important issue, since many madrasahs in South Asia are boarding schools, so that ignoring non-resident children would lead to an under-estimate of the true enrolment share of madrasahs.

For the above reasons, we are able to define madrasah enrolment in broad terms - we go beyond current enrolment by using data on "ever enrolment" and use information on resident as well as non-resident children of school age. Another peculiarity of Bangladesh is a sizeable non-Muslim population. However, since madrasahs cater exclusively to the Muslim population, we discard all non-Muslim households in our empirical analysis.

Lastly, although completion rates still remain poor, secondary school participation rate in Bangladesh has increased considerably in recent years. As a proportion of all secondary school-age (i.e. 11-18 years old) children, $72 \%$ children in our data were enrolled in secondary education. Since we are interested in explaining the proportion of secondary school going children sent to registered madrasahs, we discard data on the small fraction of households where none of the children have ever attended secondary school. Incorporating this small sub-group of households in our analysis requires joint modelling of schooling and child labour decisions. Since our primary objective is to explain household's choice of school type with a focus on religious schooling, we have abstracted away from the problem of how to decide whether to send the child to secondary school or not in the first place.

\section{Findings}

We begin by describing the variation in madrasah enrolment at the level of the household in the QSSMEB survey data. We follow Andrabi et al. (2006) and analyse enrolment choices at the household level. First, for households that have a child enrolled in a madrasah, we examine what type(s) of schools the other children in the household attend. Similarly, we repeated this exercise in households with at least one child going to a nonreligious school. Lastly, focusing on households that had at least two enrolled children we classify them as (i) “all madrasah” if all children attend registered madrasah; (ii) “mixed,” 
ifthe households had some children in school and others in madrasahs simultaneously and (iii) "all school," if all children attend school.

The results are summarized in Table 4. Among households with at least one child enrolled in a school (i.e. "school households"), 76\% of households choosing schools for at least one of their children select non-religious schools for all of their school-age children, while $18 \%$ of households sending a child to a madrasah (i.e. "madrasah households") send all of their children to madrasahs. In other words, the majority of "madrasah households" use both madrasahs and non-religious schools whilst the pattern is the opposite in case of “school households”. Among households with at least two children enrolled in secondary education, 5\% can be classified as "all madrasah" households. Therefore, a small but significant part of the variation in madrasah enrolment is between households and lends some support to the hypothesis that the choice of a madrasah in Bangladesh provides some information about the ideology of the household.

\section{Table 4:Household enrolment choices}

\begin{tabular}{lccc}
\hline & $\begin{array}{c}\text { Households } \\
\text { with at least 1 } \\
\text { school } \\
\text { enrolled child }\end{array}$ & $\begin{array}{c}\text { Households } \\
\text { with at least 1 } \\
\text { madrasah } \\
\text { enrolled child }\end{array}$ & $\begin{array}{c}\text { All } \\
\text { households }\end{array}$ \\
\cline { 2 - 4 } \% Children in non-religious school and madrasah & 23.64 & 81.69 & 22.45 \\
\% Children in madrasah only & - & 18.31 & 5.03 \\
\% Children in non-religious school only & 76.36 & - & 72.52 \\
(N) & $(1472)$ & $(426)$ & $(1550)$ \\
\hline
\end{tabular}

Note: Figures exclude children enrolled in unregistered madrasahs and based on children aged 6-18 years.

The fact that a significant part of the variation in madrasah enrolment is between households highlights the role of household-specific factors in predicting madrasah enrolment of children. Motivated by religious convictions, households may only have to "sacrifice” one child for religious education. Indeed, analysis of household responses to direct question on reasons for madrasah attendance does provide support for some of these theories. The most commonly cited reason is religious preference of the household (45.79\%), followed by perceived high quality of madrasah education (22.18\%), concerns for after-life (8.22\%) and distance to school (6.88\%). 
The significance of the variation in madrasah enrolment at the household level is also confirmed by the descriptive statistics presented in Appendix Table 1. Further insights into the underlying reasons for madrasah attendance can also be obtained by looking at the figures presented in Appendix Table 1. The first column in the Table reports mean values of key household and community-level variables. The second and third columns report the mean values of the variables at the child level separately for school and madrasah enrolled children respectively. In our sample, there are a total of 1566 children enrolled in registered secondary school/madrasah of which $19 \%$ are reported to be attending religious schools.

A number of observations can be made here. First, households whose children are enrolled in non-religious schools have higher income and better access to electricity. Second, madrasah attending children belong to more religious households. In the religious households (defined as parents praying five times every day) sub-sample, $8.89 \%$ of the households send all children to madrasa compared to a 3.48\% in non-religious household sample. However, even in the religious household sub-sample, 24\% of all households send one child to school and one to madrasah suggesting that in rural Bangladesh, both religion and economics are important in explaining school choice. Third, madrasah enrolled children live in less developed (measured in terms of average educational attainment of the villagers and road conditions) and more religious (proxied by the number of mosques) villages. Finally, the demand for madrasah schooling appears to be inversely related to the quality of non-religious schools in the area (measured in terms of test scores) - households with at least one madrasah enrolled child report living in areas with higher average madrasah test score (mathematics as well as English). The opposite pattern is noted for households with at least one non-religious school child. We now further explore these issues in a regression framework.

\section{Correlates of madrasah enrolment}

In this section, we build on simple tabulations presented earlier and formally explore the correlates of madrasah enrolment in a regression framework. We are interested in learning about the effect of variables such as household poverty, parental education, religious preference, distance to schools and community profile on school choice decisions. The study of school choice is complicated by the presence of two types of religious schools. 
Given the institutional differences between recognised and unrecognised madrasahs and the very small share of the latter in total secondary school enrolment, we discard the unrecognised ones from the regression analysis. The regression model is estimated using data on all secondary school enrolled children, leaving non-religious school as the base category type.

The regression sample contains 1229 households where 27\% households have more than 1 secondary school enrolled children. Our dependent variable of interest is the proportion of children belonging to the same household who attend madrasahs. Therefore, the dependent variable has values that fall between zero and one. Estimation of the regression model using Ordinary Least Squares (OLS) method with proportions response dependent variable is unproblematic as long as all of the proportions lie well within the unit interval (e.g. between values 0.3 and 0.7). Otherwise, the predicted values are unlikely to fall between zero and one. In other words, in cases where the variable is strictly inside the unit interval, one cannot recover the expected value of the fractional response from a linear model for the log-odds ratio. Indeed, density plots of the dependent variable reveals a significant number of proportions close to 1 and 0 (results not shown). Estimating a logit model for such data is not appropriate either - using the log-odds transformation fails when we observe responses at the corners, zero and one. This will result in missing values, and hence observations would subsequently be dropped from the estimation sample. Amongst other things, a linear functional form for the conditional mean might also miss important nonlinearities. To deal with fractional response data, one needs models for the conditional mean of the fractional response that keep the predicted values in the unit interval. For the above reasons, Papke and Wooldridge (1996) suggest using a Generalized Linear Model $^{16}$ (GLM), also known as Fractional logit, which can handle proportions of exactly 0 or $1^{17}$. However, for the sake of comparability, we also report results from OLS regression ${ }^{18}$.

\footnotetext{
${ }^{16}$ The GLM generalizes linear regression by allowing the linear model to be related to the response variable via a link function and by allowing the magnitude of the variance of each measurement to be a function of its predicted value.

${ }^{17}$ For a textbook treatment of fractional logit regression model, see Wooldridge (2002, page $\left.661 \mathrm{p}\right)$.

${ }^{18}$ For empirical studies comparing estimates of OLS and Flogit, see Wagner (2001).
} 
The choice of independent variables in our regression analysis is guided by the theoretical model of school choice discussed in Section 3. The regression model has the following controls:

a) household income (proxied by per capita expenditure; household assets; household having electricity; mother's and father's education level and age ${ }^{19}$ )

b) parental religiosity

c) distance to different types of school from the household (measured in terms of travel time, in minutes)

d) availability of registered madrasahs relative to non-religious secondary schools in the locality (i.e. union)

e) quality of registered madrasahs and non-religious schools in the locality (i.e. union)

f) average age and gender of school-age children in the household

g) village characteristics

This specification is similar to that used by Newhouse and Beegle (2006) ${ }^{20}$. However, our data is rich enough to shed light on the effect of poverty, household's religious preference and supply-side influence. Lastly, it should be pointed out that the model presented earlier abstracts away from intra-household issues i.e. we did not focus on within household variation in terms of factors that differ across children of the same household. It is wellknown in the literature on determinants of child outcomes that the demographic structure of the household matters: children of certain birth order and gender enjoy systematic advantage over their siblings in the same household (e.g. see Garg and Morduch, 1998). In particular, poor households are budget constrained and that intensifies competition amongst siblings. In this setting, children with certain demographic and possibly innate attributes may be selected for religious education. Using this framework, one can explain

\footnotetext{
${ }^{19}$ In addition, a positive coefficient on parental age may serve as a crude test of the "after-life consumption" hypothesis. Using data on Taiwan, Chang (2005) finds that (a), religious giving and charitable giving are closely related to after-life consumption and (b) older people are more likely to provide volunteer work and attend more religious activities than younger individuals.

${ }^{20}$ Their child-level regression model included the following variables: (a) household wealth (proxied by per capita expenditure and floor type of the household); (b) past academic achievement of the child (including elementary school grade repetition); (c) mother's and father's education level and religion; (d) student's sex; (e) whether the student worked in junior high; (f) the general size of the student's village at age 12; (g) the type of elementary school; (h) indicators for languages spoken at home; (i) the average district elementary score; $(\mathrm{j})$ number of schools in the district and $(\mathrm{k})$ the subjective health of the respondent.
} 
madrasa enrolment from a within household perspective. However, these issues are left for future research. Nonetheless in the empirical analysis we control for child age and gender at the household level in order to acknowledge the relevance of demographic factors.

\section{Results}

Table 5 presents the regression results following two different regression models, namely, OLS and fractional logit. Two specifications are presented for each model. The first is a parsimonious specification whilst the second additionally controls for village characteristics. The main results are as follows.

Income effect: Madrasahs charge lower fees and hence may attract children from poorer households. Households may be unable to afford admission fees, textbooks, transport and private tuition required to attend government recognised schools and hence may often find that their only option is a registered madrasah. Indeed in our theoretical model in section 3, the effect of parental income $(y)$ on the fraction of children sent to madrasahs is negative.

To test for this possibility, we included 2 dummies which capture the economic status of the household. For each household, we first compute the total food and non-food expenditure. We then work out per capita monthly household expenditure, and apply adult equivalence correction to account for scale economies arising due to differences in household demographic structure. On the basis of this variable, we calculate expenditure quartiles - the 2 dummies in our empirical specification correspond to the first 2 quartiles leaving the top 2 quartiles as the base category. If household poverty is a valid explanation for madrasah enrolment, we would expect positively signed coefficients on dummies corresponding to lower quartiles. Indeed there is some evidence in favour of the poverty hypothesis. The coefficient on the variable "Household expenditure: 2nd quartile" is always significant in all regressions (see Table 5). This is also true for the variable "Household expenditure: 1st quartile". When other proxies of household poverty are examined, the inverse relationship between household income and madrasah attendance is also confirmed. Madrasah enrolment is also found to be negatively associated with electricity connection to the household's home. 
Table 5: Household level estimation of the determinants of madrasa enrolment (Dependent variable: Proportion of enrolled school children who attended madrasahs)

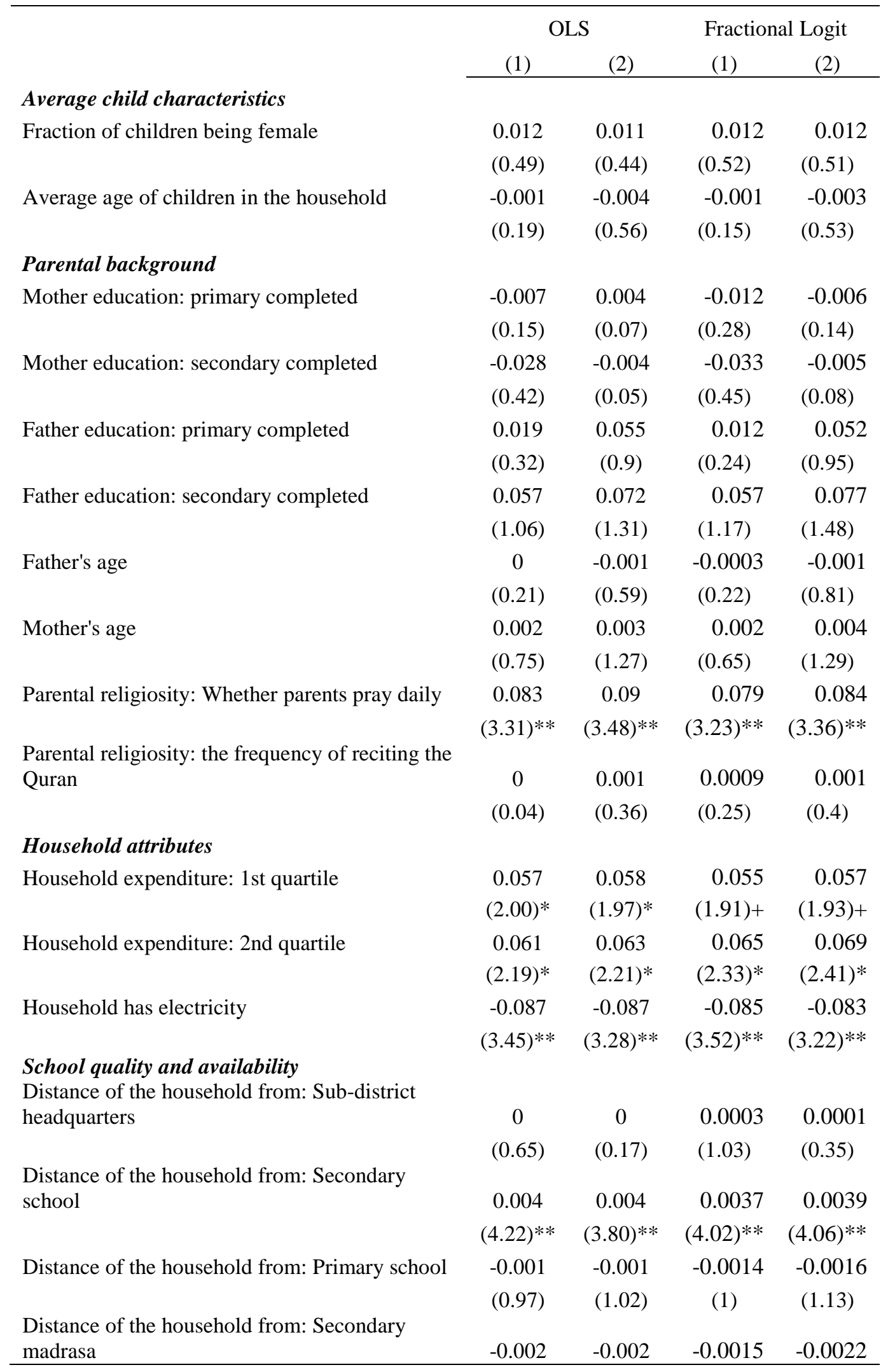




\begin{tabular}{|c|c|c|c|c|}
\hline & (1.58) & $(1.96)^{+}$ & -1.44 & $(2.11)^{*}$ \\
\hline $\begin{array}{l}\text { Distance of the household from: Primary } \\
\text { madrasa }\end{array}$ & $\begin{array}{c}-0.002 \\
(1.5)\end{array}$ & $\begin{array}{l}-0.001 \\
(1.22)\end{array}$ & $\begin{array}{l}-0.0018 \\
(1.56)\end{array}$ & $\begin{array}{l}-0.0015 \\
(1.27)\end{array}$ \\
\hline log of mean Maths score of local madrasas & $\begin{array}{l}0.002 \\
(0.07)\end{array}$ & $\begin{array}{l}-0.033 \\
(0.93)\end{array}$ & $\begin{array}{l}0.0073 \\
(0.23)\end{array}$ & $\begin{array}{l}-0.025 \\
(0.67)\end{array}$ \\
\hline log of mean Maths score of local schools & $\begin{array}{l}-0.059 \\
(0.86)\end{array}$ & $\begin{array}{l}-0.051 \\
(0.69)\end{array}$ & $\begin{array}{l}-0.076 \\
(1.12)\end{array}$ & $\begin{array}{l}-0.05 \\
(0.74)\end{array}$ \\
\hline $\begin{array}{l}\text { Number of madrasas as a fraction of all } \\
\text { secondary schools }\end{array}$ & $\begin{array}{c}0.256 \\
(1.85)^{+}\end{array}$ & $\begin{array}{c}0.408 \\
(2.64)^{* *}\end{array}$ & $\begin{array}{r}0.285 \\
(2.04)^{*}\end{array}$ & $\begin{array}{r}0.438 \\
(2.73)^{* *}\end{array}$ \\
\hline $\begin{array}{l}\text { Number of madrasas as a fraction of all primary } \\
\text { schools }\end{array}$ & $\begin{array}{l}-0.102 \\
(0.34)\end{array}$ & $\begin{array}{c}-0.164 \\
(0.5)\end{array}$ & $\begin{array}{l}-0.228 \\
(0.92)\end{array}$ & $\begin{array}{l}-0.299 \\
(1.07)\end{array}$ \\
\hline $\begin{array}{l}\text { Community characteristics } \\
\text { Village has electricity }\end{array}$ & & $\begin{array}{l}0.056 \\
(1.03)\end{array}$ & & $\begin{array}{l}0.043 \\
(0.78)\end{array}$ \\
\hline Village has pucca(paved surface) road & & $\begin{array}{l}-0.031 \\
(1.07)\end{array}$ & & $\begin{array}{l}-0.03 \\
(1.11)\end{array}$ \\
\hline Village: number of mosques & & $\begin{array}{l}-0.009 \\
(0.78)\end{array}$ & & $\begin{array}{r}-0.009 \\
(0.85)\end{array}$ \\
\hline Village has NGO educational activity & & $\begin{array}{l}-0.076 \\
(2.06)^{*}\end{array}$ & & $\begin{array}{r}-0.079 \\
(2.18)^{*}\end{array}$ \\
\hline Village: mean education of the population & & $\begin{array}{c}-0.053 \\
(3.74)^{* *}\end{array}$ & & $\begin{array}{r}-0.051 \\
(3.40)^{* *}\end{array}$ \\
\hline $\begin{array}{l}\text { Village: proportion of the population being non- } \\
\text { Muslim }\end{array}$ & & $\begin{array}{l}-0.093 \\
(0.66)\end{array}$ & & $\begin{array}{r}-0.069 \\
(0.5)\end{array}$ \\
\hline Constant & $\begin{array}{c}-0.001 \\
0 \\
\end{array}$ & $\begin{array}{l}0.149 \\
(0.63) \\
\end{array}$ & $\begin{array}{l}-3.296 \\
(2.18)^{*}\end{array}$ & $\begin{array}{l}-2.336 \\
(1.39) \\
\end{array}$ \\
\hline Observations & 1212 & 1163 & 1212 & 1163 \\
\hline Adj. R-squared & 0.08 & 0.09 & -- & -- \\
\hline Log likelihood & -- & -- & -549.15 & -523.64 \\
\hline chi2 & -- & -- & 126.35 & 140.14 \\
\hline
\end{tabular}

Note: (a) + significant at 10\%; * significant at 5\%; ** significant at 1\%. (b) Results based on sample of all children aged 11-18 years who attended secondary education. (c) Base-category for parental education is "less than 5 years of schooling". (d) Standard errors are robust to clustering-effect at village level. (e) The variable "Parental religiosity: the frequency of reciting the Quran" ranges between 1 (recites everyday) and 5 (recites once-twice in a year).

Religious preference of the household: We include two proxies of parental religiosity ${ }^{21}$ "whether prays daily" and "the frequency of reciting the Quran". In all specifications, daily prayer is positively correlated with the proportion of children enrolled in madrasah.

\footnotetext{
${ }^{21}$ Unlike in the theoretical model where parental religiosity is assumed to be a continuous index, for regression purposes, religiosity is a binary variable ( 1 if the household head prays daily; 0 otherwise). Given our current dataset, it is not possible to distinguish between different degrees of parental religiosity.
} 
This correlation could be dismissed on the ground that religiosity is simply a proxy for household poverty. However, the regression model already includes detailed control for household economic conditions. Neither can the influence of parental religiosity be attributed to the influence of local poverty ${ }^{22}$ since the correlation survives even in specification where detailed control for village characteristics is present. Nonetheless, the evidence presented here should be treated as descriptive instead of causal: whether or not the parents recite the Quran could be also affected by the school their children attend.

Access to schools: Madrasah enrolment is positively correlated with distance of the household from non-religious secondary schools. The opposite is true for distance from secondary madrasahs. This finding is consistent with the positive and statistically significant correlation obtained between madrasah enrolment and relative availability of madrasahs (as a fraction of all the secondary schools in the sample cluster).

School quality: This is measured using data on average test scores of a sample of grade 8 students in all the secondary non-religious schools and madrasahs in sample cluster (namely union) ${ }^{23}$. Irrespective of the regression specification used, the correlation between madrasah enrolment and average quality of madrasahs in the union is insignificant. The same result is obtained for the average quality of schools in the union. This finding remains unchanged irrespective of whether we use mathematics or English test scores of students to measure quality.

Community (village-specific) influence: The second specification of each regression model in Table 5included 6 correlates of village level development - village with electricity, average educational attainment of the (adult) villagers, number of mosques in the village, presence of pucca (paved surface) road in the village, proportion of nonMuslim population and village with NGO-run education programs. Of all the above

\footnotetext{
${ }^{22}$ Much of the household preference effect can be conflated by supply-side variables such as availability of formal schools and level of development of the village of development in the village of residence. It is because children from religious households may also live in villages that are underprovided in terms of the supply of various public goods.

${ }^{23}$ We use the log of average test scores which was collected from an accompanying survey of all educational institutions in the 48 sample clusters. Given that the quality variable is measured as an aggregate average, this serves as an exogenous proxy for the quality of secondary schools/madrasahs in the sample clusters.
} 
variables, only the average education of the villagers enters the regression function significantly and is positively associated with madrasah enrolment.

Robustness of the results: It should be noted that our conclusions obtained from fractional logit regression estimates presented in Table 5 remain unchanged when we pursue alternative estimation strategy, namely, OLS regressions. Lastly, a significant part of the recent growth in madrasah enrolment reflects the general increase in secondary school participation by girls across Bangladesh. Whilst registered madrasahs were historically a preserve for boys, they started admitting girls following the introduction of the "Female Secondary School Stipend Program” (FSSSP) (Asadullah and Chaudhury 2009b). To this end, we re-estimated the regression model restricting data to the sample of male children (results not reported but available from the authors). However, our results remained unchanged. This finding is interesting because it could be argued that old-age transfer, if valid, is more relevant in predicting enrolment decisions for boys. Our analysis therefore suggests that parents' perception of the old-age support from educated daughters in rural Bangladesh may be changing, an issue that needs to be examined in future research.

\section{Conclusion and policy implications}

In this paper we have examined the choice of registered madrasah education in rural Bangladesh in the context of a two-period school choice model. Our empirical analysis is based on a unique set of data that combines survey information on parents' choices and socio-economic characteristics with survey data on all schools and madrasahs that are de facto available for each family in the study area. We then assessed the choices made in terms of the characteristics of families, schools and communities.

Our findings indicate that economic considerations such as income and schooling cost dominate in the decision to educate children in registered secondary madrasahs. Poorer households, and those with worse access (and hence higher travel cost) to non-religious schools tend to enrol a larger proportion of their children in madrasahs. Although madrasah enrolment varies positively with household religiosity, we find little evidence to suggest that the average rural Bangladeshi household possesses an innate preference for madrasah education which is insensitive to economic factors. 
Our findings have important implications for education policy design. Both the theoretical model and the empirical results suggest that education policies such as increasing the supply of non-religious mainstream schools in rural locations can help raise enrolment in these schools. The theoretical model also supports policies that boost the quality of nonreligious schools. However, in contrast to the theory, we find little empirical evidence in support of policies that improve relative quality of non-religious schools. We in fact find that religious school demand does not respond to the average quality of non-religious schools and madrasahs in the locality. This finding can be explained by the fact that education quality remains low across all types of institutions in rural Bangladesh (Asadullah, Chaudhury and Dar, 2007) ${ }^{24}$.The learning premium associated with mainstream non-religious schools may not be sufficiently large so as to make a significant difference for household school choice at present. However, it is entirely possible, and indeed likely, that further investment in non-religious school quality (for example through curriculum changes or better teacher training) will favourably alter parents' perception of the premium associated with non-religious schools. Considering the fact that nonreligious schools already enjoy a resource advantage over their religious counterparts, this may turn out to be a significant policy challenge.

Alongside improving the availability and quality of non-religious schools, it is also important to address the quality issue in recognised madrasahs. Religious schooling serves an important purpose in rural Bangladesh; it not only meets the needs of parents who prefer a more religious curriculum, but in some communities, it is the only socially acceptable form of schooling for adolescent girls. Thus simply increasing the supply of non-religious schools would not in fact result in an increase in school enrolment for girls in certain areas. Therefore, the Madrasah Education Board needs to focus on modernising the madrasah curriculum as well as on teacher training and recruitment to make sure that madrasah attendance does not unduly reduce the educational attainment of those for whom madrasahs may be the only choice.

The cost of schooling has been shown to be an important factor in the household decision making process. Thus financial transfers (such as stipends or school vouchers) may be

\footnotetext{
${ }^{24}$ Other developing country studies that looked into relative quality of faith schools also obtained similar results. For instance, see Backiny-Yetna and Wodon (2009) for the Democratic Republic of Congo.
} 
used to make non-religious schools more affordable to certain households. However, this increased enrolment in non-religious schools will have positive implications for human capital accumulation only if there are concurrent policies to further improve the quality of these schools. Finally, since household income is a major determinant of school choice, it is likely that policies aimed at reducing poverty (some of which may already be in place) will have the additional impact of increasing enrolment in non-religious, mainstream schools.

In this study, we have abstracted away from the issue of demand for madrasahs which are not recognised by the state. These madrasahs have a very small market share, and their demand remains less understood considering the fact that they impart little marketable skills. In this regard, non-market explanations can be important. First, in villages where governments and economies function poorly, unrecognised madrasahs can become major suppliers of social services, political action, and coercive force ${ }^{25}$. Unrecognised madrasahs are also a potential proxy for participation in religious organizations which can help offset the negative effects of growing up in a disadvantaged environment ${ }^{26}$. Households secure their membership by sending at least one child in a madrasah. Secondly, demand for madrasah education can be also motivated by marriage-related considerations: Madrasah education can reinforce traditional values in girls which may have substantial return in the marriage market.

Therefore, a natural direction for future research on religious school choice in rural Bangladesh is to investigate the demand for these unrecognised madrasahs. From a theoretical perspective, the model in this paper can be extended to incorporate not just religious preferences of the household, but also the influence of social norms and other non-market considerations. We can also further explore parents' decisions regarding exactly which children are picked to attend madrasahs, for example, based on their ability or gender.

\footnotetext{
${ }^{25}$ See Iannaccone and Berman (2006) for a similar argument.

${ }^{26}$ Dehejia, DeLeiere, Luttmer and Mitchell (2007) report buffering effects of religious organizations on youth outcomes in the US.
} 


\section{References}

Abdalla, Raisuddin and Hussein (2004) Bangladesh Educational Assessment: Pre-primary and Primary Madrasah Education Bangladesh. Dhaka: The United States Agency for International Development (USAID).

Ahmed, A. M. (2009) “Are religious people more prosocial? A quasi-experimental study with madrasah pupils in a rural community in India,” Journal for the Scientific Study of Religion, 48, pp. 368-374.

Alderman, Harold, Peter Orazem and Elizabeth M. Paterno (2001) "School Quality, School Cost, and the Public/Private School Choices of Low-Income Households in Pakistan,” Journal of Human Resources, 36, (2), pp. 304-326.

Andrabi, Tahir, Jishnu Das, Asim Ijaz Khwaja and Tristan Zajonc (2006) "Religious School Enrollment in Pakistan: A Look at the Data," Comparative Education Review, 50(3), pp. 446-477.

Asadullah, M. Niaz (2009) "Returns to Private and Public Education in Bangladesh and Pakistan: A Comparative Analysis", Journal of Asian Economics, 20(1), pp. 77-86.

Asadullah, M. Niaz and Chaudhury, N. and Dar, A. (2007) "Student Achievement Conditioned Upon School Selection: Religious and Secular Secondary School Quality in Bangladesh", Economics of Education Review, 26(6), pp. 648-659.

Asadullah, M. Niaz and Chaudhury, N. (2009) "Holy Alliances: Islamic high schools, public subsidies, and female schooling in Bangladesh," Education Economics, 17(3), pp. 377-394.

Asadullah, M. Niaz and Chaudhury, N. (2010) "Religious schools, social values and economic attitudes: Evidence from Bangladesh", World Development, 38(2), pp. 205-217.

Backiny-Yetna, Prospere and Wodon, Quentin (2009a) "Comparing the Performance of Faith-Based and Government Schools in the Democratic Republic of Congo," MPRA Paper 16463, University Library of Munich, Germany.

Backiny-Yetna, Prospere and Wodon, Quentin (2009b) "Comparing the Private Cost of Education at Public, Private, and Faith-Based Schools in Cameroon," MPRA Paper 16464, University Library of Munich, Germany.

BANBEIS (2006) Secondary School Key Educational Indicators prepared by the Bangladesh Bureau of Educational Information and Statistics. Accessed on 15/10/2006 from website 
http://www.banbeis.gov.bd/db_bb/secondary_education_1.htm

CAMPE (2005) "The State of Secondary Education Progress and Challenges".http://www.campebd.org/content/EW_2005.htm

Chang, Wen-Chun (2005) "Religious Giving, Non-religious Giving, and After-life Consumption”, The B.E. Journal of Economic Analysis \& Policy.

Cohen-Zada, D. (2006) "Preserving religious identity through education: Economic analysis and evidence from the United States”, Journal of Urban Economics, 60, pp. 372-398.

Cohen-Zada, D. and Justman, M. (2005) “The religious factor in private education”, Journal of Urban Economics, 57, pp. 391-418.

Cohen-Zada, D. and Sander, W. (2008) "Religion, religiosity, and private school choice: Implications for estimating the effectiveness of private schools”, Journal of Urban Economics, 64(1), pp. 85-100.

Dehejia, Rajeev, Thomas DeLeiere, Erzo F.P. Luttmer and Joshua Mitchell (2007)“The Role of Religious and Social Organizations in the Lives of Disadvantaged Youth”, NBER Working Papers 13369, National Bureau of Economic Research, Inc.

Evans, A. (2008) "Madrasah Education: Necessity or Rational Choice?" Harvard International Review, Vol. 30(3).

Garg, Ashish and Jonathan Morduch (1998) "Sibling rivalry and the gender gap: Evidence from child health outcomes in Ghana," Journal of Population Economics, 11(4), pp. 471-493.

Iannaccone, Laurence and Berman, Eli (2006) "Religious extremism: The good, the bad, and the deadly”, Public Choice, 128(1), pp. 109-129.

Long, J. and Toma, E. (1998) “The determinants of private school attendance”, Review of Economics and Statistics, 70, pp. 458-479.

Neal, D (1997) "The Effects of Catholic Secondary Schooling on Educational Achievement”, Journal of Labor Economics, 15(1), pp. 98-123.

Newhouse, D., and Beegle, K. (2006) "The effect of school type on academic achievement: Evidence from Indonesia”Journal of Human Resources, 41 (3), pp. 529-557.

Papke and Wooldridge (1996) "Econometric methods for fractional response variables with an application to 401(k) plan participation rates" Journal of Applied Econometrics, 11(6), pp. 619-632. 
Sander, William (2005) “Catholics and Catholic schooling”, Education Economics13,pp. 257-268.

Sander, William (2005) “Religion, Religiosity, and Private Schools,” Catholic Education: A Journal of Inquiry and Practice,” 9(1), pp. 7-21.

Sattar, Abdus (2004) Bangladesh madrasa shikhkha o samajjibone tar provab (Madrasa education in Bangladesh and indications in social life). Dhaka: Islamic Foundation.

Wagner, J (2001) “A note on the firm size-export relationship”, Small Business Economics17, pp. 229-337.

Wodon, Quentin and Yvonne Ying (2009) "Literacy and Numeracy in Faith-Based and Government Schools in Sierra Leone”.

Wooldridge, William (2002) Econometric Analysis of Cross Section and Panel Data, Cambridge, MA: MIT Press.

World Bank (2010) "Secondary School Madrasas in Bangladesh: Incidence, Quality, and Implications for Reform”, Bangladesh Development Studies (BDS) Series no 27. 


\section{Appendix 1}

The function $v\left(\frac{a}{Z_{P}}\right)$ may be generically illustrated as follows:

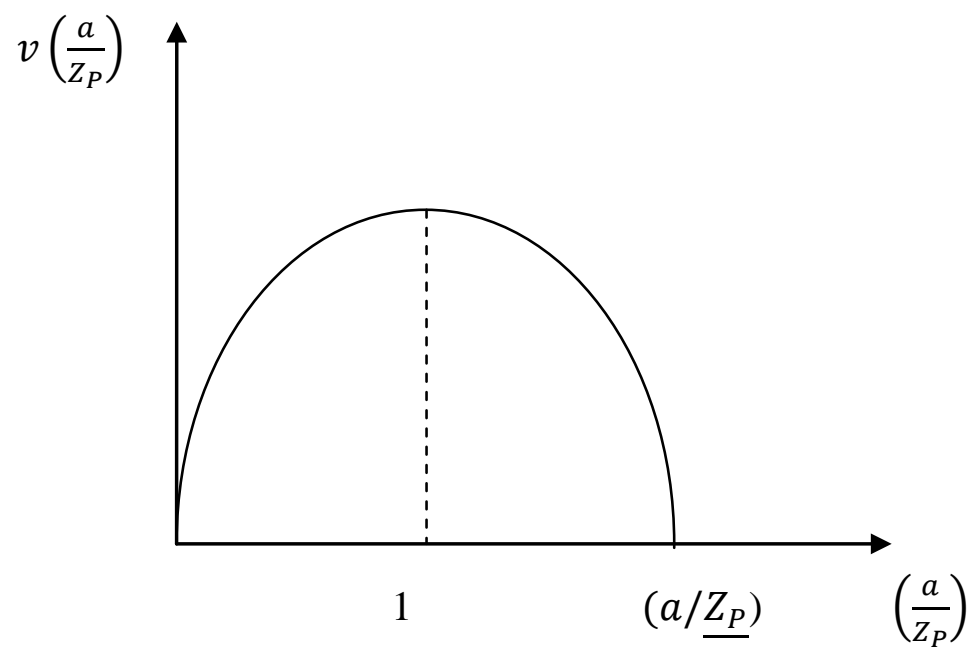




\section{Appendix Table 1: Summary statistics}

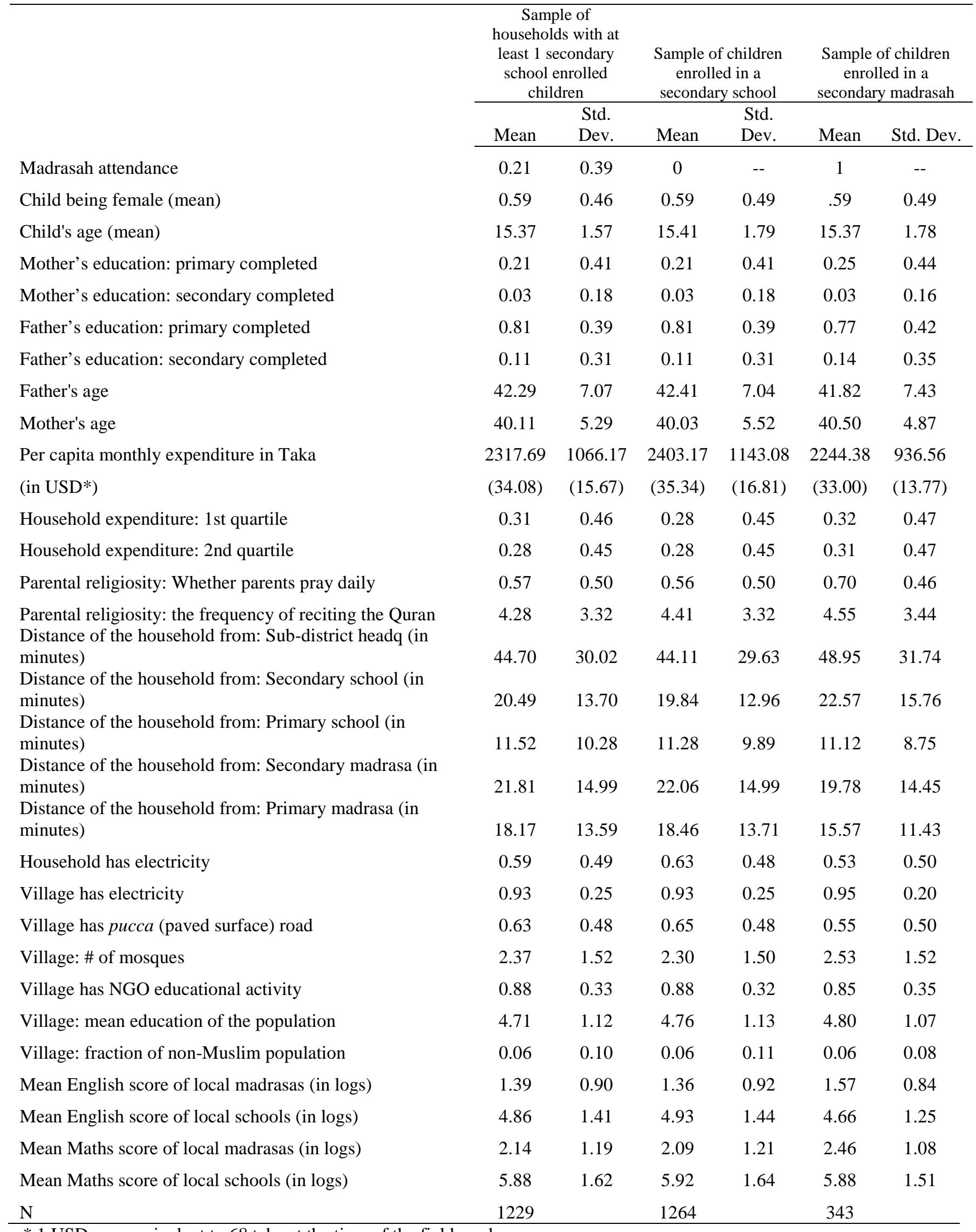

* 1 USD was equivalent to 68 taka at the time of the field work. 